\title{
ISLAMIC GUIDANCE FOR DRUG ADDICTION
}

\author{
${ }^{1}$ Agus Supriyanto \\ ${ }^{\mathbf{1}}$ Prodi Bimbingan dan Konseling, Fakultas Keguruan dan Ilmu Pendidikan, Universitas Ahmad Dahlan \\ agussupriyantospd@gmail.com
}

\begin{abstract}
Islamic Guidance is social rehabilitation program for Drug Addiction (resident). The goal of this research to know the Islamic guidance for resident at the Center for Rehabilitation of the National Narcotics Agency Lido Bogor. The methodology in this research is qualitative descriptive, with a sample two religious counselor. Can be concluded that Islamic guidance is implemented with the classical format, group format, and individual formats. The goal of the Islamic Guidance to develop religious mentally.
\end{abstract}

Keyword: Islamic, Guide, Drug Addiction

Copyright (C) 2016 IICET (Padang - Indonesia) - All Rights Reserved Indonesian Institute for Counseling, Education and Theraphy(IICET)

\section{PENDAHULUAN}

Narkoba menurut kamus narkoba dalam Pedoman Prosedur Kerja Bidang Advokasi (2011:4) adalah singkatan dari narkotika, Psikoterapi, dan bahan adiktif lain. Sedangkan kecanduan Narkoba adalah penyakit kompleks. Hal ini ditandai dengan perilaku kompleks dengan seringkali keinginan yang tidak terkendali serta konsumsi naroba yang bertahan dalam menghadapi kemungkinan yang sangat merugikan (Pipatkul, 2010:1). Kecanduan dapat menjadi kronis dengan kemungkinan kambuh bahkan setelah jangka waktu yang lama tidak menggunakan narkoba. Umumnya adalah pecandu tersebut percaya bahwa bisa berhenti dari narkoba dengan caranya sendiri.

Masalah dalam kecanduan narkoba yang berhubungan dengan kecanduan narkoba dapat bervariasi secara signifikan. Sebab pecandu narkoba bisa berasal dari semua laipsan masyarakat dan gender, yaitu dari permasalahan kesehatan mental, pekerjaan, dan kesehatan/ sosial (Pipatkul, 2010:2). Sehingga semua gangguan adiktif bisa menjadi lebih sulit, ataupun lebih terkontaminasi. Hal tersebut menjadi bagian yang tidak diinginkan oleh para pecandu.

Dalam perkembangan seseorang menjadi pecandu narkoba tidak dapat dengan sendirinya. Ada yang menyertai secara langsung maupun tidak langsung. Sehingga mendorong seseorang untuk menggunakan. Dorongan untuk menggunakan narkoba dapat mengabil dari semua aspek pada fungsi pecandu, yaitu keluarga, tempat kerja, maupun masyarakat (Pipatkul, 2010:2).

Data hasil penelitian yang dilakukan oleh BNN bekerjasama dengan peneliti dari Puslitkes Universitas Indonesia tahun 2011 didapat estimasi angka penyalahguna narkoba di Indonesia mencapai prevalensi 2,2\% dari penduduk berusia $10 \mathrm{~s} / \mathrm{d} 59$ tahun atau setara dengan 3,8 juta jiwa. Angka yang sangat besar dari jumlah penduduk di Indonesia. Kemudian ada pula pecandu laki-laki dan wanita. Walaupun dari Gambar 1.1 menjelaskan bahwa masih lebih besar pria, akan tetapi ada pula pecandu wanita. Merupakan hal yang memprihatinkan jika ada pecandu wanita. 


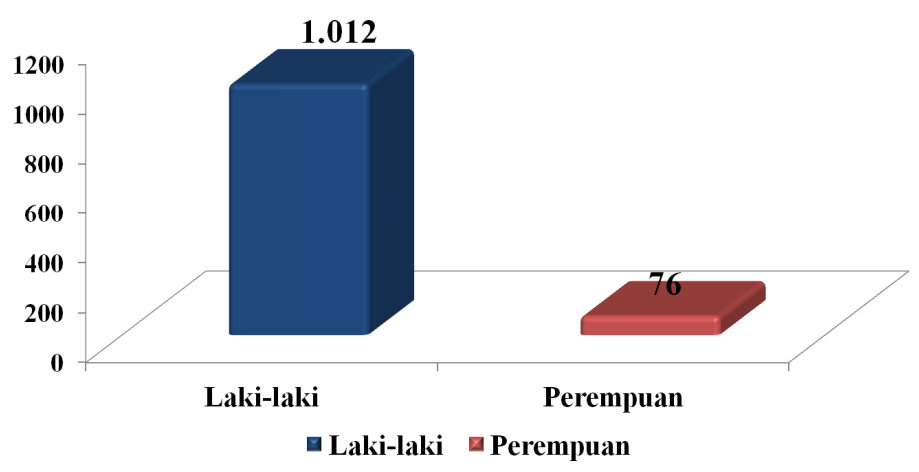

Gambar 1. Data Residen Upt Terapi \& Rehabilitasi BNN Tahun 2011 Bedasarkan Jenis Kelamin Sumber: UPT Terapi \& Rehabilitasi BNN, Maret 2012

Oleh karena itu, salah satu kebutuhan yang mendesak diidentifikasi dalam bidang terapi dan rehabilitasi oleh sebagian besar negara di wilayah ini adalah cara pencegahan yang efektif untuk mengurangi tingkat relaps yang tinggi di antara pecandu narkoba yang pulih. Dalam beberapa tahun ini, ada peningkatan jumlah program terapi dan rehabilitasi yang dilaksanakan untuk membantu peningkatan jumlah orang kecanduan narkoba. Namun banyak yang tidak memiliki bimbingan yang tepat tentang cara efisien dalam mengelola program tersebut dan standar minimum yang disyaratkan dan sesuai prosedur yang harus diikuti.

Berdasarkan data di Balai Rehabilitasi Narkoba Badan Narkotika Nasional Lido Bogor, Residen perempuan pada bulan November 2015 berjumlah 23 residen. Sedangkan Residen laki-laki berjumlah 221 residen. Dari jumlah tersebut, mengungkapkan bahwa para residen memerlukan perhatian supaya sembuh dari narkoba. Kemudian peran konselor di Balai Rehabilitasi Narkoba Badan Narkotika Nasional Lido Bogor memang sentral sebagai upaya penyembuhan dan pengembangan diri residen setelah sembuh dari jeratan narkoba. Selain itu, berdasar informasi dari konselor, bahwa residen sangat memerlukan perhatian dari keluarga untuk mengangkat mentalnya agar terhindar lagi dari narkoba, setelah keluar dari Balai Rehabilitasi Narkoba.

Dengan mencermati hal tersebut, pemerintah dalam beberapa tahun belakangan sangat gencar melakukan program pemulihan bagi korban penyalahgunaan NAPZA yaitu dengan menawarkan program rehabilitasi. Program rehabilitasi tersebut dimaksudkan untuk memulihkan kondisi biopsikososial kembali dan dapat kembali menjalani kehidupan di masyarakat nanti. Keberfungsian sosial itu sendiri merupakan suatu kondisi dimana seseorang mampu memecahkan permasalahan sosial yang dialami, mampu memenuhi kebutuhan dan mampu melaksanakan peranan sosial, secara mandiri dan normatif.

Senada dengan hasil penelitian dari Rusel (2013) mengenai "Penerapan Tindakan Rehabilitasi bagi Pelaku Tindak Pidana Narkotika berdasarkan Undang- undang No. 35 Tahun 2009 Tentang Narkotika, bahwa pecandu narkotika dan korban penyalahgunaan narkotika wajib menjalani rehabilitasi." Untuk mencapai tujuan tersebut, dalam proses rehabilitasi korban penyalahgunaan NAPZA dilakukan dengan dua tahapan program penanganan yaitu (1) rehabilitasi medis, dan (2) rehabilitasi sosial. Rehabilitasi medis dilakukan untuk memberikan perawatan kesehatan fisik kepada klien. Sedangkan pada rehabilitasi sosial ditujukan untuk mengembalikan kondisi psikis dan sosial klien. Ada ada beberapa metode yang digunakan dalam proses rehabilitasi korban penyalahgunaan NAPZA, seperti program 12 Langkah, Therapeutic Community (TC), dan lain sebagainya. Secara garis besar, kegiatan yang dilakukan dalam proses rehabilitasi meliputi (1) bimbingan fisik (olah raga, rekreasi, perawatan kesehatan), bimbingan mental psikologik (konseling, terapi kelompok, dan lain-lain), bimbingan mental keagamaan (ibadah, ceramah agama, pendidikan budi pekerti, kegiatan keagamaan, dan sebagainya), bimbingan sosial (sesi kelompok, terapi kelompok/ dinamika kelompok, simulasi, role playing, dan lain-lain), pelatihan/ bimbingan kerja (karir), bimbingan belajar, dan praktik belajar kerja. Dalam tahap ini juga dilakukan pula konseling keluarga, home visit, family support group.

Menurut tim penulis buku Penataan Pendidikan Profesional Konselor dan Layanan bimbingan dan Konseling dalam Jalur Pendidikan Formal, (2008:194) pada saat ini telah terjadi perubahan paradigma pendekatan bimbingan dan konseling, yaitu dari pendekatan yang berorientasi tradisional, remedial, klinis, 
bimbingan dan konseling perkembangan (Developmental Guidance and Counseling) atau bimbingan dan konseling komprehensif (Comprehensive Guidance and Counseling) didasarkan pada upaya pencapaian tugas perkembangan, pengembangan potensi, dan pengentasan masalah-masalah konseli. Tugas-tugas perkembangan dirumuskan sebagai standar kompetensi yang harus dicapai konseli, sehingga pendekatan ini disebut juga bimbingan dan konseling berbasis standar (Standard Based Guidance and Counseling). Ketika pendekatan bimbingan dan konseling perkembangan dipergunakan akan menggabungkan pendekatan yang berorientasi klinis, remidial, dan preventif, (Myrick, 2011:8).

Berkaitan dengan program-program tersebut, salah satu program dalam proses rehabilitasi korban penyalahgunaan NAPZA yang dapat dilakukan konselor adalah bimbingan islami. Bimbingan, sebagai upaya pendidikan, diartikan sebagai proses bantuan kepada individu untuk mencapai tingkat perkembangan diri secara optimum di dalam navigasi hidupnya secara mandiri. Bantuan dalam arti bimbingan yaitu memfasilitasi individu untuk mengembangkan kemampuan memilih dan mengambil keputusan atas tanggung jawab sendiri. Kondisi perkembangan optimum adalah kondisi dinamis yang ditandai dengan kesiapan dan kemampuan individu untuk memperbaiki diri (self-improvement) agar dia menjadi pribadi yang berfungsi penuh (fully-fungctioning) di dalam lingkungannya (Sunaryo Kartadinata, 2011:57).

Hal tersebut juga ditunjang dari Wilis (2008), yang bedasarkan hasil penelitian dengan judul "Konseling Terpadu Pemulihan Pecandu Narkoba. Dari hasil penelitian menemukan bahwa konseling terpadu terdiri dari konseling individual, konseling agama, konseling keluarga, konseling kelompok, pendidikan dan pelatihan, kunjungan, dan partisipasi sosial. Semua itu bertujuan agar klien terbebas dari dorongan kecanduan akibat mengkonsumsi narkoba." Sehingga bimbingan islami dapat digunakan konselor sebagai usaha pencegahan, pengembangan, dan penyembuhan bagi pecandu narkoba.

Bimbingan dan konseling islami adalah upaya membantu individu belajar mengembangkan fitrah dan atau kembali kepada fitrah, dengan cara memberdayakan (enpowering) iman, akal, dan kemauan yang dikaruniakan Allah SWT. Kepadanya untuk mempelajari tuntutan Allah dan Rasul-Nya, agar fitrah yang ada pada individu itu berkembang dengan benar dan kokoh sesuai tuntutan Allah SWT (Sutoyo, 2009:23). Sehingga bimbingan islami adalah bantuan yang diberikan konselor kepada klien dalam rangka memfasilitasi individu untuk mengembangkan kemampuan memilih dan mengambil keputusan atas tanggung jawab sendiri sesuai fitrahnya, sehingga berkembang iman, akal, dan kemauan yang dikaruniakan Allah SWT.

Oleh karena itu, konselor dalam hal ini perlu menguasai keilmuan bimbingan yang berlandaskan nafas islam yang mendasarkan pada Kitab Al-Qur'an dan Sunnah Rasul-Nya. Jika konselor dapat menerapkan bimbingan islami kepada klien, maka akan mental klien akan sehat. Sehingga kondisi yang memungkinkan perkembangan optimal bagi individu secara fisik, intelektual, dan emosional sepanjang hal itu tidak bertentangan dengan kepentingan orang lain (The World Federation for Mental Health, 1948 dalam Hidayat dan Herdi, 2014:30).

Oleh karena itu, penelitian ini untuk mengetahui bimbingan islami yang dilakukan oleh konselor di Balai Besar Rehabilitasi Badan Narkotika Nasional, Lido bogor. Hal ini sebagai dasar untuk mengembangkan keilmuan bimbingan dan konseling bagi pecandu narkoba. Kemudian bedasarkan latar belakang tersebut, rumusan masalah dalam penelitian ini adalah "Bagaimana bimbingan islami bagi pecandu narkoba di Balai Besar Rehabilitasi Badan Narkotika Nasional Lido Bogor?" Setelah rumusan masalah tersusun, maka tujuan penelitian ini adalah "Untuk mengetahui bimbingan islami bagi pecandu narkoba di Balai Besar Rehabilitasi Badan Narkotika Nasional Lido Bogor."

\section{METODELOGI PENELITIAN}

Penelitian ini merupakan penelitian deskriptif kualitatif dimana suatu metode penelitian yang berlandaskan pada filsafat postpositivisme yang biasanya digunakan untuk meneliti pada kondisi objektif yang alamiah dimana peneliti berperan sebagai instrumen kunci (Sugiyono, 2008:15). Kemudian penelitian kualitatif dengan studi deskriptif analitik yang dipakai dalam penelitian ini merupakan metode kualitatif untuk mendapatkan data yang mendalam, suatu data yang mengandung makna (Sugiyono, 2012:3). Sehingga dapat menyajikan secara langsung hakikat hubungan antar peneliti dan informan, objek dan subjek penelitian.

Peran penliti dalam peneliti sebagai alat peneliti utama (key instrument) yang mana melakukan proses penelitian secara langsung dan aktif mewawancarai, mengumpulkan berbagai materi atau bahan yang berkaitan dengan sistem pelaksanaan bimbingan islami di Balai Besar Rehabilitasi Badan Narkotika Nasional Lido Bogor untuk pecandu narkoba. Guna mencapai hasil penelitian, maka peneliti perlu menetapkan 
populasi dan sampel dalam penelitian ini. Populasi merupakan keseluruhan subjek penelitian (Suharsimi, 2010:173). Sedagkan sampel adalah sebagian dari populasi (Sugiyono, 2014:49).

Populasi dalam penelitian ini adalah konselor yang melaksanakan bimbingan islami bagi pecandu narkoba dengan jumlah delapan konselor agama. Delapan konselor agama yang berfokus pada agama islam dan agama kristen. Kemudian peneliti menggunakan teknik sampling yang merupakan teknik dalam pengambilan sampel (Sugiyono, 2008:81). Maka teknik pengambilan sampel dalam penelitian ini menggunakan adalah teknik sampling purposive. Sampling purposive adalah teknik penentuan sampel dengan pertimbingan tertentu (Sugiyono, 2008:85). Maka Sampel dalam penelitian ini adalah konselor agama islam berjumlah dua (2) konselor (male and female). Dua konselor dibagi menjadi satu konselor mewakili residen pria (male) dan satu konselor dari residen wanita (female).

Alat intrumen dalam penelitian ini adalah wawancara dan observasi. Wawancara yang dilakukan dalam penelitian ini menggunakan jenis wawancara semiterstruktur (indepht interview) dengan tujuan untuk menemukan permasalahan lebih terbuka, di mana pihak yang diajak wawancara diminta pendapat, dan ideidenya (Sugiyono, 2014:73). Sehingga peneliti dalam wawancara ini perlu mengumpulkan data verbal yang diperoleh melalui percakapan atau tanya jawab (Tohirin, 2012:63). Sedangkan intrument lain yang digunakan adalah observasi partisipatif dimana peneliti terlibat dengan kegiatan sehari-hari orang yang sedang diamati atau yang digunakan sebagai sumber data penelitian (Sugiyono, 2014:64). Wawancara semiterstruktur/ mendalam (indepht interview) dan observasi partisipatif menjadi bagian penting dalam penelitian ini.

Sumber data dalam penelitian ini menggunakan data primer, adalah data dalam bentuk verbal atau katakata yang diucapkan secara lisan, gerak-gerik atau perilaku yang dilakukan oleh subjek yang dapat dipercaya, yakni subjek penelitan atau informan yang berkenaan dengan variabel yang diteliti atau data yang diperoleh dari responden secara langsung (Arikunto, 2010:22). Sehingga sumber data primer dalam penelitian ini adalah dari konselor pria (male) dan konselor wanita (female) yang menaungi residen pria (male) dan residen wanita (female). Kemudian juga digunakan data sekunder, adalah data yang diperoleh dari teknik pengumpulan data yang menunjang data primer. Dalam penelitian ini diperoleh dari hasil observasi yang dilakukan oleh peneliti kepada konselor pria (male) dan konselor wanita (female) di tempat bekerja mereka sesuai jadwal dari setiap konselor agama yang berbeda-beda. Dapat dikatakan data sekunder ini bisa berasal dari dokumen-dokumen grafis seperti tabel, catatan,SMS, foto dan lainlain (Arikunto, 2010:22).

Analisis data kualitatif menurut Bognan \& Biklen (1982) sebagaimana dikutip Moleong (2007:248), adalah upaya yang dilakukan dengan jalan bekerja dengan data, mengorganisasikan data, memilahmilahnya menjadi satuan yang dapat dikelola, mensintesiskannya, mencari dan menemukan pola, menemukan apa yang penting dan apa yang dipelajari, dan memutuskan apa yang dapat diceriterakan kepada orang lain. Analisis data dalam penelitian kualitatif dilakukan sejak sebelum memasuki lapangan, selama di lapangan, dan setelah selesai di lapangan (Sugiyono, 2014:89).

\section{HASIL DAN PEMBAHASAN PENELITIAN}

Hasil dari penelitian, peneliti telah mendapatkan data meliputi (1) deskripsi informan peneliti, (2) deskripsi hasil penelitian, dan (3) pembahasan dari hasil penelitian. Pertama berkaitan dengan deskripsi diri konselor agama pria (male) dan wanita (female). Kemudian peneliti tidak diperkenankan lebih jauh untuk mengetahui informasi mengenai kegiatan bimbingan islami dari residen pria atau wanita.

1. Bapak Dodi Setiadi (Konselor Agama Islam/ Ustad)

Bapak Dodi adalah seorang pria berumur 25 Tahun yang bekerja sebagai Pegawai Negeri Sipil (PNS). Penempatan beliau bekerja di Balai Besar Rehabilitasi Badan Narkotika Nasional Lido Bogor dengan sasaran residen pria di kantor residen male. Beliau merupakan informan pertama yang diwawancarai peneliti dan berdiskusi mengenai kegiatan bimbingan islami bagi residen pria. Beliau sangat antusias untuk memberikan informasi yang peneliti butuhkan dengan tidak mengganggu kesibukan beliau dalam bekerja. Dengan penampilan yang ramah, tegas, berwibawa, lugas dalam berbicara, beliau bersedia menjawab semua pertanyaan yang diajukan peneliti. Beliau pun tidak segan-segan untuk membantu peneliti mencarikan informan lainnya agar bersedia menjadi informan dalam penelitian serta mencarikan data-data yang berguna bagi kesempurnaan penelitian ini. Tidak ada perasaan canggung dalam diri peneliti karena peneliti dan beliau telah saling mengenal sejak sebelum peneliti melakukan penelitian, sehingga membantu peneliti menemukan informasi mengenai bimbingan islami bagi pecandu narkoba dengan sasaran residen pria.

2. Ibu Yunia Wulandari (Konselor Agama Islam/ Ustadzah) 
Ibu Wulan adalah seorang wanita berumur 25 Tahun yang bekerja sebagai Pegawai Negeri Sipil (PNS). Penempatan beliau bekerja di Balai Besar Rehabilitasi Badan Narkotika Nasional Lido Bogor dengan sasaran residen wanita di kantor residen female. Peneliti cukup kesulitan untuk memperoleh informasi dari beliau mengenai kegiatan bimbingan islami. Di awal proses wawancara, beliau masih terkesan menutupi dan enggan untuk membagi informasi, disebabkan bukan muhrim (berbeda jenis kelamin). Hal tersebut dapat peneliti pahami mengingat beliau ustadzah. Kemudian dari hasil evaluasi peneliti, informasi dari Ibu Yunia dapat diberikan melalui pertemuan antara peneliti, Ibu Yunia, dan Ibu Nurlita Hendiani. Kemudian peneliti melakukan pertemuan yang kedua kalinya, dan mengubah gaya wawancara yang semula bersifat formal menjadi lebih cair dan berbentuk "sharing". Baru pada pertemuan kedua tersebut beliau mau terbuka membicarakan kegiatan bimbingan islami di Balai Besar Rehabilitasi Badan Narkotika Nasional Lido Bogor dengan sasaran residen wanita. Gaya dan nada bicara beliau santun, jawaban-jawaban yang diberikannya pun bersifat to the point, sehingga membantu peneliti menemukan informasi mengenai bimbingan islami bagi pecandu narkoba dengan sasaran residen wanita.

Dari analisis deskriptif data penelitian adalah analisis pada data yang diperoleh dari hasil wawancara dua (2) informan yang mewakili, yaitu Konselor Dodi dan konselor Yulia. Keduanya berfokus pada konselor agama islam, dan menangani residen pria maupun wanita yang beragama islam. Berdasarkan hasil wawancara dengan narasumber atau informan, maka peneliti dapat menganalis tentang bimbingan islami bagi pecandu narkoba di Lingkungan Balai Besar Rehabilitasi Badan Narkotika Nasional Lido Bogor, meliputi (1) bimbingan islami dengan format klasikal, (2) bimbingan islami dengan format kelompok, dan (3) bimbingan islami dengan format individual. Ketiga klasifikasi bimbingan islami tersebut diberikan kepada residen pria dan ataupun wanita untuk menumbuhkan mental keagamaan yang berkaitan dengan proses rehabilitasi sosial para residen saat rehabilitasi dan setelah keluar dari rehabilitasi. Berikut hasil analisis yang terbagi menjadi tiga (3) klasifikasi bimbingan islami.

1. Bimbingan Islami dengan Format Klasikal

Bedasarkan hasil penelitian dengan intrumen observasi dan wawancara, maka salah satu bimbingan islami yang dilaksanakan di Balai Besar Rehabilitasi Badan Narkotika Nasional Lido Bogor dapat diklasifikasikan dalam format klasikal. Bimbingan islami format klasikal dapat dibagi menjadi beberapa kegiatan yang menunjang pengembangan spiritual dan mental residen, serta wajib diikuti oleh residen pria ataupun wanita. Berikut kegiatan bimbingan islami dengan format klasikal bedasarkan hasil penelitian, yaitu:

a. Ibadah bersama

Ibadah bersama merupakan kegiatan yang wajib diikuti oleh residen. Ibadah ini dilaksanakan di masjid yang ada di Balai Besar Rehabilitasi Badan Narkotika Nasional Lido Bogor. Ibadah ini dikoordinasikan oleh konselor agama islam yang telah tersusun jadwal untuk setiap hari, setiap minggu, maupun setiap bulan, serta selama satu tahun. Tujuan ibadah bersama ini untuk menumbuhkan nilai-nilai spiritual (iman dan takwa), menjalin solidaritas antar residen, dan menjalin kedekatan dengan Allah SWT.

b. Ceramah Agama

Ceramah agama di Balai Besar Rehabilitasi Badan Narkotika Nasional Lido Bogor untuk residen pria maupun wanita relatif sama walaupun pelaksanaanya dilakukan sendiri-sendiri oleh konselor pria (male) dan wanita (female). Ceramah agama dilaksanakan dengan program yang telah disusun oleh konselor agama islam dengan frekuensi setiap hari, setiap minggu, dan setiap bulan. Setiap hari, ceramah agama dilakukan setelah shalat subuh dan antara sholat magrib serta isya, sehingga ceramah agama dilakukan oleh konselor yang berbeda dengan jadwal masing-masing. Kemudian jadwal ceramah agama setiap minggu dilaksanakan pada hari jum'at, pada saat shalat jum'at dengan sasaran adalah residen pria ataupun wanita. Sedangkan ceramah agama yang dilaksanakan setiap bulan dilakukan minimal satu kali dengan jadwal hari minggu ataupun hari libur yang berkaitan dengan hari libur islam. Tujuan ceramah agama ini adalah untuk menanamkan nilainilai spiritual (Iman dan Takwa) bagi residen dan membekali residen pentingnya menjauh dari jeratan narkoba.

c. Pendidikan Budi Pekerti

Pendidikan budi pekerti bagi residen dijadwalkan setiap minggu dan setiap bulan. Kegiatan ini dilakukan melalui kerjasama antara konselor agama dan konselor pembina mental, sehingga adanya kesinambungan kegiatan yang telah diprogramkan. Pendidikan budi pekerti ini diharapkan untuk menumbuhkan iman, takwa, kepribadian dan sosial dari residen.

2. Bimbingan islami dengan format kelompok

Hasil dari penelitian melalui informasi (observasi dan wawancara), didapatkan hasil bahwa pelaksanaan bimbingan islami yang dilakukan oleh format kelompok dilakukan dengan bimbingan kelompok atau diskusi antara konselor agama sebagai pemimpin kelompok dengan residen sebagai 
anggota kelompok. Kegiatan ini digunaka konselor agama untuk mengembangkan diri residen agar mantap untuk menjauhi narkoba saat rehabilitasi ataupun setelah rehabilitasi. Kegiatan ini merupakan sharing antara residen satu dengan residen lain, tetapi konselor agama sebagai pemimpin diskusi.

3. Bimbingan islami dengan format individual.

a. Konsultasi bagi Residen

Konsultasi dalam bimbingan islami dilaksanakan bagi residen yang ingin berkonsultasi untuk mengembangkan spiritual dan mental residen. Konsultasi ini dapat dilaksanakan secara terprogram maupun isidental sesuai keinginan residen maupun kejadian yang terjadi selama residen melaksanakan rehabilitasi di Balai Besar Rehabilitasi Badan Narkotika Nasional Lido Bogor. Konsultasi agama yang terprogram dapat dilakukan setiap bulan dalam rangka mengetahui perkembangan diri residen dari sisi keagamaan, spiritual, dan mental. Sedangkan konsutasi isidental, dilaksanakan sesuai keinginan residen dan melalui kejadian yang terjadi oleh residen secara individual maupun kelompok kecil atau besar.

b. Konsultasi bagi Keluarga Residen

Konsultasi dalam bimbingan islami dilaksanakan bagi keluarga residen yang ingin berkonsultasi untuk mengetahui kondisi perkembangan keluarga. Konsultasi ini dapat dilaksanakan secara terprogram maupun isidental perkembangan residen maupun kejadian yang terjadi selama residen melaksanakan rehabilitasi di Balai Besar Rehabilitasi Badan Narkotika Nasional Lido Bogor. Konsultasi agama bagi keluarga yang terprogram dapat dilakukan setiap bulan dalam rangka mengetahui perkembangan diri residen dari sisi keagamaan, spiritual, dan mental. Sedangkan konsutasi dengan orang tua secara isidental, dilaksanakan sesuai keinginan keluarga residen dan melalui kejadian yang terjadi oleh residen secara individual maupun kelompok kecil atau besar.

Tabel 1. Kegiatan Bimbingan Islami di Balai Besar Rehabilitasi Badan Narkotika Nasional Lido Bogor

\begin{tabular}{|l|l|l|}
\hline No. & \multicolumn{1}{|c|}{ Format Kegiatan } & \multicolumn{1}{c|}{ Kegiatan } \\
\hline 1. & \multirow{2}{*}{ Format Klasikal } & Ibadah Bersama \\
\cline { 3 - 3 } & & Ceramah Agama \\
\cline { 3 - 3 } & & Pendidikan Budi pekerti \\
\hline 2. & Format Kelompok & Bimbingan Kelompok \\
\hline 3. & Format Individual & Konsultasi dengan Residen \\
\cline { 3 - 3 } & & Konsultasi dengan orang Tua \\
\hline
\end{tabular}

\section{PEMBAHASAN}

Bedasarkan hasil penelitian bahwa kegiatan bimbingan islami di Balai Besar Rehabilitasi Badan Narkotika Nasional Lido Bogor dilaksanakan oleh konselor agama islam yang sasarnnya adalah residen yang bergama islam pula, tetapi terbagi antara residen pria dan wanita dengan konselor pria dan konselor wanita. Sehingga tujuan utama dari bimbingan islami ini untuk mengembangkan spiritual (Iman dan Takwa) residen dan mengembangkan mental residen saat rehabilitasi atau setelah rehabilitasi sebagai bagian rehabilitasi sosial. Hal tersebut senada dengan definisi bimbingan dan konseling islami yaitu sebagai upaya membantu individu belajar mengembangkan fitrah dan atau kembali kepada fitrah, dengan cara memberdayakan (enpowering) iman, akal, dan kemauan yang dikaruniakan Allah SWT. Kepadanya untuk mempelajari tuntutan Allah dan Rasul-Nya, agar fitrah yang ada pada individu itu berkembangdengan benar dan kokoh sesuai tuntutan Allah SWT (Sutoyo, 2009:23).

Kemudian jika konselor dapat menerapkan bimbingan islami kepada klien, maka akan mental klien akan sehat. Sehingga kondisi yang memungkinkanperkembangan optimal bagi individu secara fisik, intelektual, dan emosional sepanjang hal itu tidak bertentangan dengan kepentingan orang lain (The World Federation for Mental Health, 1948 dalam Hidayat dan Herdi, 2014:30).

Bimbingan islami dapat dilaksanakan dengan tiga format, yaitu yaitu (1) bimbingan islami dengan format klasikal melalui kegiatan ceramah agama, pendidikan budi pekerti, dan ibadah bersama, (2) bimbingan islami dengan format kelompok melalui kegiatan bimbingan kelompok (materi keagamaan), dan (3) bimbingan islami dengan format individual melalui proses konsultasi bagi residen maupun keluarga residen. Ketiga format tersebut telah di program oleh konselor agama selama satu tahun. Akan tetapi menurut Myrick (2011: 423), bahwa meskipun konselor sekolah bertanggungjawab merencanakan program, kerjasama dan dukungan semua pihak, serta administrator sangat penting bagi keberhasilan program. Oleh karena itu 
konselor agama tidak bisa bekerja sendiri, perlu melaksanakan kolaborasi antara konselor agama dengan konselor agama lain dan juga konselor lain serta pemimpin dan administrasi untuk mendukung program kegiatan.

\section{KESIMPULAN DAN SARAN}

Bedasarkan hasil penelitian mengenai Bimbingan Islami bagi Pecandu Narkoba di Balai Besar Rehabilitasi Badan Narkotika Nasional Lido Bogor, dapat dimpulkan bahwa bimbingan islami yang dilaksanakan dapat dibagi menjasi tiga format bimbingan, yaitu (1) bimbingan islami dengan format klasikal melalui kegiatan ceramah agama, pendidikan budi pekerti, dan ibadah bersama, (2) bimbingan islami dengan format kelompok melalui kegiatan bimbingan kelompok (materi keagamaan), dan (3) bimbingan islami dengan format individual melalui proses konsultasi bagi residen maupun keluarga residen. Tujuan dari bimbingan islami tersebut untuk mengembangkan mental keagamaan bagi pecantu narkoba (residen) dengan konselor agama sebagai pelaksananya. Bimbingan islami dilaksanakan dengan membagi jenis kelamin sebagai sasaran maupun pelaksananya (konselor) di kantor Male dan Female.

Bedasarkan hasil kesimpulan tersebut, maka disarankan bagi pakar bimbingan dan konseling untuk pecandu narkoba untuk mengembangan secara teoritis mengenai bidang bimbingan konseling adiksi (pecandu narkoba) dan praktik layanan bimbingan dan konseling bagi pecandu narkoba. Sehingga dengan terciptanya kajian teoritis dan praktik mengenai bimbingan dan konseling bagi pecandu narkoba diharapkan peran konselor sebagai pencegahan, pemberantasan, dan penyembuhan penyakit narkoba.

\section{DAFTAR PUSTAKA}

Arikunto, Suharsimi. 2010. Prosedur Penelitian Suatu Pendekatan Praktik. Yogyakarta: Rineka Cipta.

Butar, Darwin Butar. 2012. Data Residen Upt Terapi \& Rehabilitasi BNN Tahun 2011. Jakarta: UPT Terapi \& Rehabilitasi BNN, Maret 2012.

Cursel, Carlina. 2013. Penerapan Tindakan Rehabilitasi bagi pelaku Tindak Pidana Narkotika Bedasarkan Undang-undang No. 35 Tahun 2009 Tentang Narkotika. Mataram: Unversitas Mataram

Depdiknas. 2008. Penataan Pendidikan Profesional Konselor dan Layanan Bimbingan dan Konseling Dalam Jalur Pendidikan Formal. Jakarta : Depdiknas.

Hidayat, Dede Rahmat dan Herdi. 2014. Bimbigan Konseling (Kesehatan Mental di Sekolah). Bandung: PT. Remaja Rosdakarya.

Manafe, Yappy. 2011. Pedoman Prosedur Kerja Bidang Advokasi. Pencegahan Pemberantasan Penyalahgunaan dan Peredaran Gelap Narkoba (P4GN). Jakarta: BNN, Deputi Bidang Pencegahan Direktorat Advokasi.

Moleong Lexy, J. 2007. Metode Penelitian Kualitatif. Bandung: PT. Remaja Rosdakarya.

Myrick, Robert D. 2011. Developmental Guidance and Counseling : A Practical Approach Fifth edition. Minneapolis : Educational Media Corporation.

Piptakul, Kitipan Kanjana. 2010. Manajemen Program Terapi dan Rehabilitasi di Asia. Jakarta: Program Penasihat Narkoba Colombo Plan.

Sugiyono. 2008. Metode Penelitian Kuantitatif, Kualitatif, dan R\&D. Bandung: Alfabeta. 2012. Metode Penelitian Kuantitatif, Kualitatif, dan R\&D. Bandung: Alfabeta. 2014. Memahami Penelitian Kualitatif. Bandung: Alfabeta.

Sunaryo Kartadinata.2011. Menguak Tabir Bimbingan dan Konseling sebagai Upaya Pedagogis. Bandung : UPI Press.

Sutoyo, Anwar. 2009. Bimbingan dan konseling Islami (Teori\& Praktik). Semarang: CV. Widya Karya.

Tohirin. 2012. Metode Penelitian Kualitatif (Dalam Pendidikan dan Bimbingan Konseling). Jakarta: PT. Raja Grafindo Persada.

Wilis, Sofyan S. 2008. Konseling Terpadu Pemulihan Pecandu Narkoba. Jakarta: depdiknas.go.id, Editorial Jurnal Pendidikan dan Kebudayaan Edisi 36. 